\title{
THE PRACTICES AND OBSTACLES OF ENGLISH LANGUAGE TEACHING IN INTELLECTUAL DISABILITY CLASSROOM: A CASE STUDY AT SPECIAL SCHOOL (SLB) IN PALEMBANG
}

\author{
Dalilan $^{1}$ \\ Library Science Study Program, Faculty of Humanities, Universitas Islam Negeri Raden Fatah \\ Palembang 30126, Indonesia \\ (putrada888@gmail.com) \\ Eka Sartika ${ }^{2}$ \\ English Education Study Program, Faculty of Tarbiyah dan Ilmu Keguruan, Universitas Islam Negeri \\ Raden Fatah Palembang 30126, Indonesia \\ (ekasartika_uin@radenfatah.ac.id) \\ Indah Deyana Lestari ${ }^{3}$ \\ English Education Study Program, Faculty of Tarbiyah dan Ilmu Keguruan, Universitas Islam Negeri \\ Raden Fatah Palembang 30126, Indonesia \\ (Indahdeyana1905@gmail.com)

\begin{abstract}
Individuals with disabilities learn with difficulties such as physical, emotional, mental, and social deficiencies. In a limited physical and mental condition, they are faced with problems in learning, particularly in learning English. This study aims at revealing practices and obstacles in learning English in an intellectual disability classroom that affected the teaching practices. A case study method was used in this study. This study's participants were two teachers at SLB-C Tuna Grahita Palembang selected by a typical sampling technique. The observation and interview were used to collect data regarding realized practices and obstacles in teaching English to students with intellectual disabilities. Data were analyzed using thematic analysis. The study results indicated that English language teaching practices in intellectual disability classrooms were similar to the regular ones but more oriented to students' needs. The obstacles of English language teaching were affected by intellectual disability students' limitations in writing, reading, speaking, listening skils, and heterogeneous ability.
\end{abstract}

Keywords: Intellectual Disability; English Language Teaching; Special School

First Received:

(February 19, 2021)
Final Proof Received:

(March 29, 2021)

\section{INTRODUCTION}

Individuals with disabilities are facilitated to have a proper education in a special school. It is known as Sekolah Luar Biasa (SLB) in Indonesia. It accepts students with learning difficulties such as physical, emotional, mental, social efficiencies, also proven intelligence and special gifted (Kemendikbud, 2016b: 10). Based on the Ministry of National Education Republic of Indonesia's statistics data in 2016, the total of handicapped students in Indonesian special schools is 24.985 students in which intellectual disability has the most number of students with 1.489 students 
Dalilan, Eka Sartika, \& Indah Deyana Lestari, The Practices and Obstacles of English ...

(Kemendikbud, 2016a: 3). In other words, intellectual disability is the most case in Indonesian special schools.

Following that, the term of intellectual disability is referred to a condition of having limitations in cognitive and adaptive skills because of impairment. American Psychiatric Association or APA clarifies that individual with intellectual disability has general mental abilities impairments during the developmental period that impact in intellectual functioning including reasoning, problem-solving, planning, abstract thinking, judgment, academic learning, and learning experience (American Psychiatric Association (APA), 2013). Subsequently, students with intellectual disabilities struggle in learning. They face difficulties understanding new skills and studying slower than other students of the same age (Association for Higher Education Access \& Disability (AHEAD), 2011: 15).

Although facing difficulties in learning processes, intellectual disability students still have the potential to learn a language successfully. Rondal (2000) reports learning foreign language seems to be in the capacity of intellectual disability children; they who are raised by bilingual parents may develop bilingualism to a certain degree. Krapez (2010) states children with mild intellectual disability may have foreign language communicative ability by using professional teaching and learning approaches. In the effort of teaching English to intellectual disability students, AHEAD suggests teachers use shorter sentences, present information in a sequence, restructure tasks, or make assignments simpler and give students extra time to do it (Association for Higher Education Access \& Disability (AHEAD), 2011). Further, teachers should ensure that the materials and tasks they use in the classroom are organized and implemented to students' needs and abilities (Otanjac, 2016: 471). In the end, it is still possible for intellectual disability students to learn the English language well.

In the preliminary study at SLB-C Tuna Grahita Karya Ibu Palembang, intellectual disability students learn English 2 hours a week. English instruction is arranged by Indonesian Educational Ministry regulations under curriculum 13 (K-13). But, it was found that the teachers did not apply the English teaching practice in accordance with the curriculum. The teachers mentioned that students couldn't cope with the syllabus as the other regular students in general schools do because the students with intellectual disability students had low cognitive abilities. Therefore, it was essential to know the English teaching practices and the reasons this case happened.

Some researchers had conducted similar researches with this study. Arifah analyzed learning implementation for fifth-grade intellectual disability students in Gunungdani. The study results showed that special schools' learning process was a bit different from the regular ones because the delivered material was adjusted to students' assessments (Arifah, 2014). Then, Sari found the English teacher's activities in instructing the students consisted of three activities: preparation, application, and evaluation. Then, teaching problems faced by the teacher were difficulty in communicating with the students, 
students' limited vocabulary and short memories, and students' different ability in hearing and understand the lessons, also the poorly supported school facilities (Sari, 2017). Last, Nadhiroh found that the teaching materials in the class were simple vocabulary and simple sentences with realia, audiovisual/video, and pictures as teaching media (Nadhiroh, 2017). While the most used strategy by the teachers was Total Physical Response (TPR).

Although many studies explored English teaching and learning in a special school, not many of them focused on English language teaching practices in intellectual disability classrooms and students' obstacles that affected the practices. Most of the studies observed English teaching practice with physical impairments students and did not specifically address English subject but to several subjects. Last, little or no study investigating students with intellectual disability has been conducted in Palembang. Therefore, it is interesting to find the way of English teaching practices in intellectual disability classroom and to know students' obstacles affecting the practices.

\section{LITERATURE REVIEW}

\section{The Concept of Special School}

In Indonesia, Special School is known as Sekolah Luar Biasa (SLB). Based on Indonesia Law Constitution No. 72 of 1991, Indonesian special school accepts students with disabilities from three main categories: 1) physical disability such as deaf students, blind students, and so on, 2) mental disability including mental retardation or intellectual disability students, and 3) personality disorders. Moreover, Darma and Rusyidi state that special school is divided into five areas, namely SLB A for students with visual impairment, SLB B for students with hearing impairment, SLB C for students with mental retardation or intellectual disability, SLB D belongs to students with orthopedically handicapped and SLB E for students with delinquency (Darma \& Rusyidi, 2015).

\section{The Concept of Intellectual Disability}

Intellectual disability or tuna grahita (Indonesian language) is a term used for a neurodevelopmental disorder. Individuals with intellectual disability have poor intellectual function with an intellectual quotient (IQ) equals to or less than 70 and poor adaptive behavior; conditions cover everyday social and practical skills then the onset is determined before age 18 years or during the developmental period (American Psychiatric Association (APA), 2013: 31; Iqbal et al., 2016: 28; Schalock \& Luckasson, 2004: 139; Tomac et al., 2017:. 144; Vasconcelos, 2004: 71) emphasize that intellectual disability is the onset affects academic performance, it is diagnosed based on Intellectual Quotient or IQ and adaptive behavior areas such as social behavior which includes interpersonal skills, interaction and play, dealing with conflict and interpreting social cues or body language, then intellectual performance includes memory, learning rate, abstract 
concept, and information process and speech and language development which includes articulation of speech, vocabulary and understanding the nuances of meaning. On the whole, intellectual disability means impairment that causing individuals to have restricted cognitive, social, and self-care abilities.

\section{Types of Intellectual Disability}

Measuring people's IQ is the most common way to consider people's mental ability. Vasconcelos stated that a person is considered normal when they have more than 85 points on their IQ test, described having borderline intellectual functioning if the score ranging 71 to 84 test and regarded having an intellectual disability if their score below 70 (Vasconcelos, 2004). Iqbal and Tomac categorize people with intellectual disability on the basis of their IQ level comprising of mild intellectual disability with IQ level 50-70, moderate intellectual disability with IQ level 35-49, severe intellectual disability with IQ level 20-34, and profound intellectual disability with IQ level below or less than 20 (Iqbal et al., 2016; Tomac et al., 2017).

\section{Characteristics of Intellectual Disability Students}

People with intellectual disabilities vary physically and emotionally. Based on Shree and Shukla, the characteristics of people with intellectual disabilities can affect their academic learning (Shree \& Shukla, 2016). Furthermore, Hornby (2014) explains that children with a mild or moderate intellectual disability typically have problems in realizing self-academic learning, such as short attention span, difficulty understanding instructions, difficulty learning reading, writing, and number skills, delayed speech and language skills. Difficulties with fine and gross coordination skills and immature behavior.

\section{The Practice of English Language Teaching to Intellectual Disability Students}

Sedlak and Sedlak explain some ways to develop language skills such as listening and writing for intellectual disability students (Sedlak \& Sedlak, 1985). In terms of listening skills, their ability can be developed by improving gross sound discrimination, speech sound discrimination, listening to others, self-monitoring skill, and skills in listening for directions. To recognize vocabulary and its usage skill, students with intellectual ability can be helped by teaching and/or reviewing the vocabulary items, using real objects, demonstrations, and pictures, associating new words with something already familiar to the group and pointing out familiar objects, and question-and-answer games. Meanwhile, skills in written expression can be developed by practicing the following: guide the thinking of the class and read the written sentences and/or questions as a group.

Using language to relate concepts and generalizations is another problem faced by intellectual disability students. Sedlak and Sedlak (1985) pointed out that language skill associating with concepts of sequences and generalizations can be increased by developing skills in sequencing events, improving skills in associations and abstracting, 
developing and expanding skills in generalizing and applying the information to practical situations that involve the members of the class, and also developing and expanding the ability to select or reject alternatives in order to arrive at a decision regarding a problem presented.

Practicing verbal expression and motor expression is a particularly typical problem for the students. Skill in verbal expression can be developed by increasing awareness of speech and speech production and by work to improve the overall intelligibility of oral communication. Skills in motor expression can be promoted by the following efforts (Sedlak and Sedlak, 2015). Those skills involve encouraging the students to respond with appropriate facial and/or body responses, encouraging the students to pantomime daily activities, encouraging the students to dramatize a familiar nursery rhyme or story, encouraging the students to respond appropriately to music, teaching the accompanying actions and/or rhythm, and requiring the communication of a message through gestures.

\section{Intellectual Disability Students' Obstacles in the Practice of Language Teaching}

Students with intellectual disability own particular obstacles in the language class. Sedlak \& Sedlak (1985) elucidated the obstacles such as limited knowledge of relationships (e.g. self and environment and among objects), reduced verbal communication (e.g. little verbalization at all and shorter lengths of response), limited ability with oral communication, limited vocabulary or depressed vocabulary skills, poorly developed grammatical skills, articulation problems, and limited receptive skills (i.e. limitations in listening, limitations in understanding, and hearing loss)

\section{METHOD}

In this study, data collection was done using observation and interviews administered to two of four English teachers of Junior High School in Special School (SLB) Karya Ibu Palembang. The observation checklist and interview protocol used in this study were adapted from Sedlak and Sedlak (1985). The observation checklist consisted of twenty-nine items with a yes or no scale. The observation process in which the practices and activities of English teaching and learning took place in the class was watched, listened to, and recorded. Meanwhile, a semi-structured interview was applied. In the interview process, the first teacher (initial $\mathrm{MH}$ ) was asked and recorded using the cellular phone. The same process was also done to the second teacher (initial N). Additional questions were raised to explore more information from the participants. All interview data were then transcribed. In analyzing the data of the study, thematic analysis was used. Data were organized in document files and read very carefully and repeatedly to know the meanings of the data. Then, the data were separated into codes and re-analyzed to make the themes based on the codes. The themes are reviewed, redefined, and renamed to be more complex. 


\section{RESULTS AND DISCUSSION}

\section{Results}

This study's research findings comprised the results of the practices of English language teaching for intellectual disability classroom and students' obstacles that affected the English language teaching practices.

\section{The Practices of English Language Teaching for Intellectual Disability Classroom}

It was found that the practices of English language teaching in intellectual disability classroom were similar to the regular ones but more oriented to students' needs. The themes and codes were presented in the following table:

\section{Table 1.}

Themes and codes of the practices of English language teaching for intellectual disability classroom

\begin{tabular}{lll}
\hline No & \multicolumn{1}{c}{ Theme } & \multicolumn{1}{c}{ Codes } \\
\hline 1. $\quad \begin{array}{l}\text { The practice of English teaching and } \\
\text { learning in an intellectual disability } \\
\text { classroom was similar to the regular one. }\end{array}$ & A. $\begin{array}{l}\text { The classes covered pre-activities, } \\
\text { while-activities, and post-activities. }\end{array}$ \\
& $\begin{array}{l}\text { B. The students followed the class well. } \\
\text { C. The students communicated and } \\
\text { interacted in good ways. }\end{array}$ \\
\hline $\begin{array}{l}\text { English language teaching and learning in } \\
\text { intellectual disability classrooms were } \\
\text { more oriented to students' needs. }\end{array}$ & $\begin{array}{l}\text { A. Teaching materials were adjusted to } \\
\text { students' ability. }\end{array}$ \\
& $\begin{array}{l}\text { B. } \begin{array}{l}\text { The students were not forced to reach a } \\
\text { goal. }\end{array} \\
\text { C. The teachers were the center of the class. }\end{array}$ \\
& $\begin{array}{l}\text { D. The teachers gave more reinforcements in } \\
\text { explaining teaching materials. }\end{array}$ \\
\hline
\end{tabular}

The themes and codes described in the table are detailed as follows:

\section{English language teaching and learning in an intellectual disability classroom was similar to the regular one}

Based on the data obtained through observation and interview, it was found that the practices of English language teaching and learning in intellectual disability classes were similar to the regular ones. The practices covered: 1) well-paced class activities; preactivities, while-activities, and post-activities, 2) intellectual disability students could follow the English class well. And 3) intellectual disability students could communicate and interact in good ways.

At first, based on the classroom observations, it was found that the process of English teaching included pre-activities, whilst-activities, and post-activities. The teachers always started the class by checking students' background knowledge; the teachers gave some questions related to the materials that would be taught. Then s/he attracted the students' attention by showing interesting teaching materials and asking them to give attention to him/her. The teachers motivated the students so they would be ready to learn 
the new subjects. Next, the teachers explained the materials in understandable language and used some examples and illustrations in whilst-activities. The teachers applied the lecturing strategy as a teaching method and mostly used realia and pictures as teaching media. And, the teachers evaluated the lesson before the class ended as the post-activity. The teachers gave a short review and asked whether the students understand the materials. In the interview, teacher $\mathrm{H}$ confirmed, "I apply the same steps in the practice of English language teaching to intellectual disability students, including warming up activities, core activities, and closure activities" (personal communication, December 12, 2019).

Second, the intellectual disability students followed English class well. They paid attention to their teachers and did everything being instructed to them, such as reading words that written on the whiteboard. Next, they raised their hands before answering teachers' questions, asked the teachers' confusing materials, and stayed in their seats during the lesson. The intellectual disability students could learn English in their capacities. The teachers confirmed it in the interview. Teacher H claimed, "Generally, intellectual disability students can follow English classes well. As you can see, the students learned English actively but, they will not understand complicated materials" (personal communication, December 12, 2019). In the same thought, teacher N said that "In English class ummm. Our students have intellectual disability in their studying capability (thinking) ummmm but they can follow the class well, they are same as normal students. They can keep silence when I ask them to do it, their behavior is great" (pesilentcommunication, December 13, 2019).

Last, the intellectual disability students communicated and interacted with people around them in good ways. During the classroom observation, the students responded to their teachers and had good feedback. They tried to answer each time their teachers asking questions, and when they couldn't, they would tell their teachers that they did not know the answer. Then, the students were very polite; they respected their teachers and cared with their friends. Also, the students were obedient to the school regulations. Based on the interview data, teacher $\mathrm{H}$ explained that "It is not really difficult for the students to adapt with others. They can interact well in their daily activities with their intellectual disability friends and their teachers at school. But, they may have difficulties communicating with people with other disabilities, for example, speaking with a deaf person. About adapting to school rules, they know their schedules; they come immediately to their class as soon as the bell is ringing" (personal communication, December 12, 2019). Following this, teacher $\mathrm{N}$ also stated the same thing "Actually, the students don't face any difficulties to adapt to their school environment. They are mature enough, and they know each other, so it helps. As the teacher, I treat them like my friends. I don't have any troubles in interacting with them" (personal communication, December 13, 2019). 
Dalilan, Eka Sartika, \& Indah Deyana Lestari, The Practices and Obstacles of English ...

\section{The practices of English language teaching and learning in intellectual disability classroom was more oriented to students' needs}

Based on observation and interview data, it was found that the process of English language teaching and learning in intellectual disability classroom was more oriented to students' needs. The teaching practices were fitted to students' abilities by the following: 1) major material of English subject was adjusted to students' capabilities, 2) the students were not forced to reach a goal, and 3) the teachers were the centers of all of the class activities, and 4) the teachers gave reinforcements to the student.

In the first place, the classroom observation data showed that there was no deep application of language four skills in the process. In all of the class observations, the teachers set a teaching topic and explained the class's related words. The given new words ranged from five to fifteen words; they were easy and familiar to them. Teacher $\mathrm{N}$ confirmed that "In English lesson, the way I teach is like... (thinking) uuhh they have limited brain ability comparing to the students without an intellectual disability, so I give them the easier materials. I teach them the basic materials such as numbers in English, I tell them the English of 1-50 then they follow me, it is the system I apply in my class. It is an introduction to English vocabulary" (personal communication, December 13, 2019). With the same idea, teacher $\mathrm{H}$ said, "They will not understand complicated materials. The students just learn English introduction which is basic vocabulary" (personal communication, December 12, 2019).

Secondly, based on observation data, intellectual disability students were not forced to reach a goal in English teaching practice. The students just imitated the things done by their teachers. From the observation data, they received teaching material, then tried to understand it and copied it. Although it seems easy, some students still faced difficulties in understanding the material. Teacher $\mathrm{H}$ confirmed that "They just read the words that I wrote on the whiteboard, they repeat the words I said and re-write the words on the whiteboard" (personal communication, December 12, 2019). Furthermore, teacher N states that "Curriculum is covered with a set of goals that is difficult to be achieved by the students. As a teacher, I know my students' capabilities. I don't target my students to be able to do this and do that in each meeting. When students understand the material, it's enough for me" (personal information, December 13, 2019).

Thirdly, based on observation data, teachers were the center of all of the activities in intellectual disability class. There was no discussion, worked in pair, group assessments, or role-playing in the process of English language teaching and learning. The teacher was the only resource for the students to learn English in the class. It was confirmed by teacher $\mathrm{H}$ who said, "I don't use them. My students can't handle them because they have low comprehension. Our discussions are not advance as normal students, they just ask the things they don't know, and I answer their questions" (personal communication, December 12, 2019). 
Finally, the teachers gave more reinforcement in delivering English teaching material in intellectual disability class from observation data. Practically, the teachers gave and explained the materials that consisted of five to fifteen words in front of the class, next, s/he showed the way to say new words several times, then s/he asked each of students about the words, then drill it again to make sure the students memorizing the words with the meanings and able to pronounce the words well. In the interview, the confirmation was delivered by teacher $\mathrm{N}$ who said, "Some of them can do it (memorize the lesson), and it's hard for the others but, they will be able to do it if we teach the materials repeatedly" (personal communication, December 13, 2019). Then, when it was still hard for the students, the teachers would visit students' seats one by one. It was done to check students' understanding because some of them needed more attention and helps.

\section{The Students' Obstacles that Affected the Practices of English Language Teaching in Intellectual Disability Classroom}

It was found that there were some obstacles on students' parties that affected the practices of English language teaching. The students had limitation in English language skills such as writing, reading, speaking, and listening. Then, they also had different abilities in learning English. The themes and codes from the observation and interview data were listed in table 2 .

Table 2.

Themes and codes of the students' obstacles that affected the practices of English language teaching in intellectual disability classroom

\begin{tabular}{|c|c|c|}
\hline No. & Themes & Codes \\
\hline 1. & $\begin{array}{l}\text { Intellectual disability students' writing } \\
\text { limitation. }\end{array}$ & $\begin{array}{l}\text { A. The students couldn't write their thoughts } \\
\text { into English sentences. } \\
\text { B. The students did not know about English } \\
\text { word structures or grammar. }\end{array}$ \\
\hline 2. & $\begin{array}{l}\text { Intellectual disability students' reading } \\
\text { limitation. }\end{array}$ & $\begin{array}{l}\text { A. The students needed time to read in English. } \\
\text { B. The students couldn't comprehend English } \\
\text { texts. }\end{array}$ \\
\hline 3. & $\begin{array}{l}\text { Intellectual disability students' } \\
\text { speaking limitation. }\end{array}$ & $\begin{array}{l}\text { A. The students were not able to say English } \\
\text { words clearly. } \\
\text { B. The students couldn't speak their thoughts. }\end{array}$ \\
\hline 4. & $\begin{array}{l}\text { Intellectual disability students' } \\
\text { listening limitation. }\end{array}$ & $\begin{array}{l}\text { A. The students were just able to listen to } \\
\text { simple words mentioned by their teachers. }\end{array}$ \\
\hline 5. & $\begin{array}{l}\text { Intellectual disability students' } \\
\text { heterogeneous ability to learn English. }\end{array}$ & $\begin{array}{l}\text { A. The students had different lesson retention } \\
\text { abilities. }\end{array}$ \\
\hline
\end{tabular}

The themes and codes described in the table are detailed as follows: 
Dalilan, Eka Sartika, \& Indah Deyana Lestari, The Practices and Obstacles of English ...

\section{Intellectual disability students' writing limitation}

Based on the data obtained through observation and interview, it was found that one of the intellectual disability students' obstacles to learning English was their limitation in writing skills. The students were not able to put their thoughts in English sentences and did not understand English word structures or grammar.

Firstly, both of the teachers said that writing English sentences was really difficult for intellectual disability students from the interview data. Teacher $\mathrm{H}$ claimed that "The students can't produce English sentences and can't develop their ideas. No, they can't write a complete sentence on their own" (personal communication, December 12, 2019). Teacher $\mathrm{N}$ also said, "Writing English sentences? (laugh), they can't do it because of their low intelligence. They just understand and write words that I taught them. Writing English sentences by themselves is too difficult for them" (personal communication, December 13, 2019). Writing is very challenging to be taught to intellectual disability students. It is a complex process involving ideas. Observation data showed that the students just transcribed their thoughts orally with their mother language. They did not know the values and phases of writing that covered generating an idea, planning, composing, and revising.

Another finding also showed that intellectual disability students did not know about English structure or grammar. In the interview, teacher N confirmed, "I can't teach English grammar or structures to the students because of their intellectual disability. Their IQ is lower than average, so it is too difficult for the students to understand the grammar" (personal communication, December 13, 2019). It was by teacher $\mathrm{H}$, who said that "Learning about English grammar is not in the students' capacities" (personal communication, December 12, 2019). Based on observation data, the students didn't learn English rules. They didn't have any knowledge about kinds of written text, grammar, punctuation, or capitalization.

\section{Intellectual disability students' reading limitation}

The observation and interview data showed that intellectual disability students had a limitation in reading. The students needed time to read English words and couldn't comprehend English texts.

Initially, based on the interview data result, both of the teachers agreed that most intellectual disability students did not read in English. Teacher $\mathrm{H}$ clarified that "The students do not read written texts, they just read English words that I gave in the teaching practices" (personal communication, December 12, 2019). With a similar statement, teacher N said, "In English class, they can't read complete sentence instantly. Most of the students do not really try to read but copy the words that I mentioned when I was demonstrating the words" (personal communication, December 13, 2019). The observation data showed that reading instruction for intellectual disability students in English subject was applied visually. Students remembered the words in pairs with the pictures, real 
objects, or the translation that showed to them in the class. When they were asked to read English words, they took time to determine the letters before blending them. Practically, most of them did not totally read the words but just recognized English words with their sights effortlessly.

Then, from the observation data, reading comprehension was not included in teaching materials. Intellectual disability students had limited English vocabulary stock, didn't have grammatical knowledge, and couldn't apply context when reading. Subsequently, intellectual disability students couldn't make inferences about unknown words and couldn't understand the text as a whole.

\section{Intellectual disability students' speaking limitation}

Based on the observation and interview data, it was found that intellectual disability students had a limitation in speaking. Students' speaking limitation included unclear pronunciation and lacked of English speaking rules.

Firstly, the students did not learn English speaking powerfully. They just learned English words and pronounced the words imperfectly. Teacher $\mathrm{N}$ clarified that "The students speak unclearly but we can understand them, for example, when they say eye or ear" (personal communication, December 13, 2019). In addition, teacher $\mathrm{H}$ mentioned that "Not all intellectual disability students can say words clearly even in their own first language. Some of them have speech problems since they were born. It makes their articulation difficult to understand" (personal communication, December 12, 2019). The students never spoke in English except repeating the words mentioned by their teachers from the observation data. During the lesson, the teachers gave chances to every student to say the words. When it came to their turns, the students tried their best to demonstrate it. Still, it was not easy for them. The students pronounced the words unclearly but, understandable in terms of their context. Therefore, to the students who were born with speaking difficulties, it was their limitation, but the others may practice harder to be better.

Secondly, during the observation, it was found that the intellectual disability students couldn't express their feelings or thoughts in English speaking. To speak well, the students need to master another set of English proficiency involving vocabulary and grammar that were still challenging for intellectual disability students. Also, they did not have any idea to speak in English with intonation, stress, and pitch that convey meaning. Therefore, the students couldn't speak in English well because they lacked knowledge to construct the words or sentences.

\section{Intellectual disability students' listening limitation}

Based on the data obtained through observation and interview, it was found that intellectual disability students' impairments brought them not to have enough chances to learn English listening skill. From the interview, teacher $\mathrm{H}$ confirmed that "Intellectual disability students cannot learn listening as the other students, they cannot understand 
native speaker's voice. Even when I ask them to write the words verbally by using dictation, they can't do it" (personal communication, December 12, 2019). Likewise, teacher N said that "The students don't learn listening. Actually, we have sound system that can be used as one of English teaching media but we don't use it. We are afraid it will be dangerous for them. The intellectual disability students don't know the device's function, they may break it because they have big curiosity" (personal communication, December 13, 2019). There was no sound system, recorder, or other tools used to support listening activities in English class for the intellectual disability students during the observation. The students were just able listening simple words mentioned by their teachers. They could understand the meaning of the words by looking at the teaching media used by the teachers. During the practice, the students could follow the sounds made by the teachers orally.

\section{Intellectual disability students' heterogeneous ability}

Based on observation and interview data, each intellectual disability students had diverse lesson retention ability. They did not process the lesson in the same way. In the interview session, teacher $\mathrm{N}$ said that "Some of the intellectual disability students can do it (memorize the lesson) and it's hard for the others" (personal communication, December 13, 2019). Similarly, teacher $H$ mentioned, "The students have different IQ levels. So, their abilities to understand the lesson are diverse too" (personal communication, December 12, 2019). In the observation, some students looked very active in the learning process. They raised their hands several times and wanted to answer teachers' questions even it belonged to their friends. Meanwhile, the others faced difficulties remembering the materials. Even though they got some clues, they gave wrong answers and needed more explanation to understand the lesson.

\section{Discussion}

Based on the results of data analysis by using thematic analysis, The following findings were revealed: 1) the practices of English language teaching in intellectual disability classroom were similar to the regular ones and 2) the practices of English language teaching and learning in intellectual disability classroom were more oriented to students' needs.

At first, it was found that the practices of English teaching and learning in intellectual disability classes were similar to the regular ones. The research findings showed that the steps of English teaching in intellectual disability class consisted of preactivities, whilst-activities, and post-activities. Then, the teachers used the lecturing method and media such as realia and pictures to support the instructional process. It is consistent with Arifah (2014). In her research, she found that teaching English to intellectual disability students was the same as those of normal students. The teacher applied to lecture with a questioning-answering system and gave assignments as the 
teaching method. In the classroom, the English teachers used realia and pictures frequently (Arifah, 2014).

Furthermore, it was also found that intellectual disability students could follow the class as well as general students. The students communicated and interacted in good ways with people around them at the school. This opposed to the research carried out by Bawa and Osei, which revealed that intellectual disability students had poor participation in English class. They were not paying attention and either lying on the floor or fidgeting and putting up impulsive behaviors (Bawa \& Osei, 2018).

Secondly, it was found that the practices of English language teaching and learning in intellectual disability classroom were more oriented to students' needs. Intellectual disability students were taught vocabulary as their main subject in English lessons. It was because they had lower cognitive ability than normal students. In this case, the teachers had full authority in the teaching and learning activities. This was also revealed by Arifah, who stated that teaching materials for intellectual disability students were different from normal students (Arifah, 2014). The teachers gave easier materials for students with intellectual disability. Specifically, the English teacher delivered second grader's materials to fifth-grade intellectual disability student which covered English vocabulary only.

Since the students had heterogeneous ability to learn English, the practices of English teaching in intellectual disability classroom had more reinforcements. Teachers should do repetitions and make individual approaches in explaining English materials. Along with this, the study conducted by Avianta, Asib and Drajati revealed that teachers needed to explain teaching materials several times, individually, and orally (Avianita et al., 2018). Most of intellectual disability students tended to miss teachers' explanations in the process of teaching and learning.

Concerning the second research question aiming at finding out the students' obstacles that affected the practices of English language teaching, it was found that there were several students' obstacles impacting the processes of English teaching and learning in intellectual disability class such as writing limitation, reading limitation, speaking limitation, listening limitation, and heterogeneous ability.

In terms of writing, intellectual disability students had writing limitation. Based on the research findings, intellectual disability students had difficulties putting their thoughts into sentences. This finding is confirmed with that in the research conducted by Wong (2000). He exposed that the participants struggled to express ideas in writing clearly. They wrote a bit, they took a long to complete ideas, and they tended to translate in writing. Then, it was also found that intellectual disability students didn't know about the rules of writing English sentences (Wong, 2000). Sousa in her study, stated that intellectual disability students didn't have enough ability to follow writing rules, punctuation, spelling, grammar, and syntax (Sousa, 2001). 
In terms of reading, it was found that intellectual disability students had reading limitation in the English language teaching and learning practices. The students took longer to determine the letters before blending them when asked to read English words. Most of them did not totally read the words but just recognized English words with their sights. This is according to Hoogeveen, Smeeth, and Lancioni who stated that intellectual disability students had difficulties in discriminating letters and letter-sound acquisition and difficulties analyzing phonemes and blend phonemes into words (Hoogeveen et al., 1989). This is also supported by Mosito, Warnick, and Esambe, who found that the biggest difficulties faced by intellectual disability students in reading lacked of word recognition. The students couldn't recall the given words (Mosito et al., 2017).

In speaking, intellectual disability students' speaking limitation also brought difficulties in the practice of English language teaching. Research findings showed that intellectual disability students did not speak clearly. In line with this finding, Hofman, Terband, Snik, and Maassen found out that intellectual disability had reduced speech in speaking. This limitation may cause misunderstanding, frustration, and lost interest by communication partners (Hofman et al., 2016).

Concerning listening, intellectual disability students had the listening limitation. The research findings revealed the chance of the students to train their listening skills was not wide open. The teachers didn't allow intellectual disability students to use media that may help them develop their listening ability. This is also found by Zudeta and Mumpuniarti, who pointed out that teacher didn't provide learning activities that may improve students' understanding in listening (Zudeta \& Mumpuniarti, 2019). The students were still the object of learning whom only listen to teacher's explanation.

Regarding retention ability, the research findings revealed that each of intellectual disability students had different lesson retention ability. Their abilities to memorize the lesson were not at the same level. It is in line with Avianta who revealed that intellectual disability students' capabilities were diverse (Avianita et al., 2018). For instance, student A had difficulty in writing and likely to miss one or two alphabet(s) in writing, but he was better than student $B$ who needed a longer time to write and finish his assignments. Then, student A could read better than student B who just could read syllable by syllable. Yet, student B remembered vocabulary slower than student A.

\section{CONCLUSION}

English language teaching and learning in intellectual disability classroom have indicated particular practices. Vocabulary teaching was specifically stressed. The students with very low intellectual ability cannot think in complex ways using sentences in expressing ideas. A few words must be introduced to them to avoid them from thinking hard. In helping them to learn vocabulary, mimicking and repeating word by word are the best practices. In teaching the meaning of words, the teacher must bring in the real objects 
of the words in the classroom. In other words, the the original objects of the words must be introduced to the students in order that they can see them without thinking of the things in complex way. Because of their very limited intelligence, showing or demonstrating the pictures of the objects in the classroom is also the best way to help them understand and judge the word meaning as represented in their mental thinking pattern. The intellectual disability students cannot be taught concurrently at the same time, in the sense that the teaching approach must be individual. Their low ability of thinking does not allow them to show their verbal and motor expression correctly. To facilitate them to get more understanding, coming close physically to every single individual is the best practice. These realities suggested that learning vocabulary instead of language four skills must be emphasized. The students' poor participation and communication were the particular obstacles to developing their English language skills such as reading, writing, and speaking. These limitations challenge English teachers to find out specific adjustments, approaches, and strategies in teaching English to students with intellectual handicaps.

\section{REFERENCES}

American Psychiatric Association (APA). (2013). Diagnostic and Statistical Manual of Mental Disorders (5th ed.). Philadelphia: American Psychiatric Association.

Arifah, I. (2014). Pelaksanaan Pembelajaran bagi Siswa Tuna Grahita di Kelas 5 SD Gunungdani, Pengasih, Kulon Progo [Skripsi, Universitas Negeri Yogyakarta]. https://eprints.uny.ac.id/14328

Association for Higher Education Access \& Disability (AHEAD). (2011). Teaching and Learning: Making Learning Accessible for Students with Disabilities in Further Education. AHEAD Educational Press.

Avianita, Asib, A., \& Drajati, N. A. (2018). The Strategy in Teaching English Vocabulary for Students with Special Needs: A Narrative Inquiry Study. Journal of Education and Human Development, 7(2), 66-70.

Bawa, A.-H., \& Osei, M. (2018). English Language Education And Children With Intellectual Disabilities. International Journal of Development and Sustainability, 5(11), 27042715.

Darma, I. P., \& Rusyidi, B. (2015). Pelaksanaan Sekolah Inklusi di Indonesia: Prosiding Penelitian dan Bina Pengabdian Kepada Masyarakat. Vol 2, No 2, 223-227.

Hofman, M. C. C., Terband, H., Snik, A. F. M., \& Maassen, B. A. M. (2016). Speech Characteristics and Intelligibility in Adults with Mild and Moderate Intellectual Disabilities. Folia Phoniatr Logop, 68, 175-182.

Hoogeveen, F. R., Smeets, P. M., \& Lancioni, G. E. (1989). Teaching Moderately Mentally Retarded Children Basic Reading Skills. Research in Development Disabilities, 10(1), $1-18$.

Iqbal, M., Baig, M. A., Bhinder, M. A., \& Zahoor, M. Y. (2016). Factors Causing Mental Retardation. Asian Journal of Natural and Applied Sciences, 5(3), 28-37. 
Dalilan, Eka Sartika, \& Indah Deyana Lestari, The Practices and Obstacles of English ...

Kemendikbud. (2016a). Gambaran Sekolah Inklusif di Indonesia: Tinjauan Sekolah Menengah Pertama. Jakarta: Pusat Data dan Statistik Pendidikan dan Kebudayaan.

Kemendikbud. (2016b). Indonesia Educational Statistics in Brief 2015/2016. Jakarta: Pusat Data dan Statistik Pendidikan dan Kebudayaan.

Krapez, S. (2010). Second Language Comprehension And Acquisition In Mentally Disabled Children-Illusion $\quad$ Or $\quad$ Reality. IBS Newsletter Porocevalec. http://porocevalec.ibs.si/en/component/content/article/42-letnik-1-t-3/136-staakrape-ma-ed-applied-linguistics-second-language-comprehension-and-acquisitionin-mentally-disabled-children-illusion-or-reality

Mosito, C. P., Warnick, A. M., \& Esambe, E. E. (2017). Enhancing Reading Abilities of Learners with Intellectual Impairments through Computer Technology. African Journal of Disability, Vol. 6. https://doi.org/10.4102/ajod.v6i0.206.

Nadhiroh, S. (2017). A Study on Teaching and Learning Vocabulary for Disable Students at $S L B \quad B$ Negeri Tulungagung [Skripsi, IAIN Tulungagung]. https://repo.iaintulungagung.ac.id/6955

Otanjac, M. I. (2016). Students With Language Learning Disabilities and Difficulties In A Foreign Language Classroom. Specijalna Edukacija I Rehabilitacija, 15(4), 461-474.

Rondal, J. A. (2000). Bilingualism In Mental Retardation: Some Prospective Views. Saggi, Child Development and Disabilities, 26(1), 57-64.

Sari, D. A. (2017). Teacher's Obstacles: Teaching English for Deaf Learners at Seventh Grade of SLB Negeri Surakarta [Skripsi, IAIN Surakarta]. http://eprints.iainsurakarta.ac.id/1279

Schalock, R. L., \& Luckasson, R. (2004). American Association on Mental Retardation's Definition, Classification, and System Supports and its Relation to International Trends and Issues in the Field of Intellectual Disabilities. Journal of Policy and Practice in Intellectual Disabilities, 1(3), 136-146.

Sedlak, R. A., \& Sedlak, D. M. (1985). Teaching The Educable Mentally Retarded. New York: SUNY Press.

Shree, A., \& Shukla, P. C. (2016). Intellectual Disability: Definition, Classification, Causes and Characteristics. Intellectual Disability: Definition, Classification, Causes And Characteristics, 7(1), 9-20.

Sousa, D. A. (2001). How The Special Needs Brain Learns. Thousand Oaks: Corwin Press.

Tomac, V., Puseljic, S., Skrlec, I., Andelic, M., Kos, M., \& Wagner, J. (2017). Etiology and The Genetic Basis of Intellectual Disability In Pediatric And Population. Southeastern European Medical Journal, 1(1), 144-153.

Vasconcelos, M. M. (2004). Mental Retardation. Journal De Pediatria, 80(2), 71-82.

Wong, B. Y. L. (2000). Writing Strategies Instruction for Expository Essays for Adolescents With and Without Learning Disabilities. Topics in Language Disorders, 20(4), 29-44.

Zudeta, E. \& Mumpuniarti. (2019). Listening Skill of Mild Intellectual Disability. Advances in Social Science, Education and Humanities Research, 104-108. 


\section{APPENDIX}

\section{Observation Checklist of English Language Teaching Practice in Intellectual Disability Classroom}

Teacher's Name

Date

Time

Class

Observer

\begin{tabular}{|c|c|c|c|c|}
\hline No & Statement & Yes & No & Note \\
\hline 1 & $\begin{array}{l}\text { The teacher uses noisemakers in teaching } \\
\text { English. }\end{array}$ & & & \\
\hline 2 & The teacher uses recordings in teaching English. & & & \\
\hline 3 & $\begin{array}{l}\text { The teacher invites the students to get outside } \\
\text { classroom to identify outdoor noises. }\end{array}$ & & & \\
\hline 4 & $\begin{array}{l}\text { The teacher demonstrates the speech } \\
\text { production by using speech helper (tongue, lips, } \\
\text { and teeth). }\end{array}$ & & & \\
\hline 5 & $\begin{array}{l}\text { The teacher encourages the students to improve } \\
\text { skills in listening to other people. }\end{array}$ & & & \\
\hline 6 & $\begin{array}{l}\text { The teacher asks the students to monitor their } \\
\text { own listening improvement. }\end{array}$ & & & \\
\hline 7 & $\begin{array}{l}\text { The teacher uses real objects to teach new } \\
\text { English words. }\end{array}$ & & & \\
\hline 8 & $\begin{array}{l}\text { The teacher uses demonstrations to teach new } \\
\text { English words. }\end{array}$ & & & \\
\hline 9 & $\begin{array}{l}\text { The teacher uses pictures to teach new English } \\
\text { words. }\end{array}$ & & & \\
\hline 10 & $\begin{array}{l}\text { The teacher associates new English word } \\
\text { and/or lessons with something familiar to the } \\
\text { group. }\end{array}$ & & & \\
\hline 11 & $\begin{array}{l}\text { The teacher teaches the concept of sequences in } \\
\text { English. }\end{array}$ & & & \\
\hline 12 & $\begin{array}{l}\text { The teacher teaches the concept of } \\
\text { generalizations in English. }\end{array}$ & & & \\
\hline 13 & $\begin{array}{l}\text { The teacher teaches the students to look at } \\
\text { people's faces when they speak. }\end{array}$ & & & \\
\hline
\end{tabular}




\begin{tabular}{|c|c|c|c|}
\hline 14 & $\begin{array}{l}\text { The teacher lets the students know the } \\
\text { movements of face and lips when speaking. }\end{array}$ & & \\
\hline 15 & $\begin{array}{l}\text { The teacher puts students' hand in front of the } \\
\text { lip to allow them to feel the air during speech. }\end{array}$ & & \\
\hline 16 & $\begin{array}{l}\text { The teacher teaches English speech articulation } \\
\text { to the students individually. }\end{array}$ & & \\
\hline 17 & $\begin{array}{l}\text { The teacher teaches English pitch to the } \\
\text { students individually. }\end{array}$ & & \\
\hline 18 & $\begin{array}{l}\text { The teacher teaches English stressed to the } \\
\text { students individually. }\end{array}$ & & \\
\hline 19 & $\begin{array}{l}\text { The teacher teaches English voice to the } \\
\text { students individually. }\end{array}$ & & \\
\hline 20 & $\begin{array}{l}\text { The teacher teaches grammatical skills to each } \\
\text { student. }\end{array}$ & & \\
\hline 21 & $\begin{array}{l}\text { The teacher teaches the students to use } \\
\text { complete sentences. }\end{array}$ & & \\
\hline 22 & $\begin{array}{l}\text { The teacher teaches the students to describe } \\
\text { something in detail. }\end{array}$ & & \\
\hline 23 & $\begin{array}{l}\text { The teacher acquaints specific speech and } \\
\text { language situations to the students (for example } \\
\text { teaching the proper use of the telephone). }\end{array}$ & & \\
\hline 24 & $\begin{array}{l}\text { The teacher encourages the students to } \\
\text { response with different emotion in certain } \\
\text { situation (for example playing music with } \\
\text { various moods such as happiness, sadness, fear, } \\
\text { etc). }\end{array}$ & & \\
\hline 25 & $\begin{array}{l}\text { The teacher encourages the students to do role- } \\
\text { playing or to demonstrate their daily activities. }\end{array}$ & & \\
\hline 26 & $\begin{array}{l}\text { The teacher encourages the students to } \\
\text { dramatize a familiar nursery rhyme when it is } \\
\text { read. }\end{array}$ & & \\
\hline 27 & $\begin{array}{l}\text { The teacher plans activities that require the } \\
\text { communication of a message through gestures } \\
\text { such as 'help', 'I am hungry, etc. }\end{array}$ & & \\
\hline 28 & $\begin{array}{l}\text { The teacher encourages the students to } \\
\text { construct English sentences by themselves. }\end{array}$ & & \\
\hline 29 & $\begin{array}{l}\text { The teacher teaches the students to read the } \\
\text { written sentences. }\end{array}$ & & \\
\hline
\end{tabular}

